\title{
A HYDROXYCOUMARIN ARSCOTIN FROM Artemisia scotina
}

\author{
M. I. Yusupov and G. P. Sidyakin
}

UDC 547.587

We have continued the separation of the combined lactones from Artemisia scotina Nevski [1] by chromatography on neutral alumina (activity grade III). Elution with benzene and with benzene-methanol $(9: 1$ and 8:2) has given a substance with the composition $\mathrm{C}_{11} \mathrm{H}_{10} \mathrm{O}_{5}, \mathrm{mp} 192-193^{\circ} \mathrm{C}$ (methanol), $\mathrm{R}_{f} 0.16$ [benzenemethanol ( $9: 1)$ system; Silufol], mol, wt. 222 , which we have called arscotin.

IR spectrum, $\nu_{\max }, \mathrm{cm}^{-1}$ : $3350(\mathrm{OH}), 1710$ ( $\mathrm{C}=\mathrm{O}$ of a lactone), 1610, 1575, 1500 (aromatic ring). coumarins.

UV spectrum: $\lambda \max 258,312 \mathrm{~nm}(\log \varepsilon 3.63,3.95)$, which is characteristic for trisubstituted hydroxy-

The NMR spectrum (taken on a JNM $4 \mathrm{H}-100 / 100 \mathrm{MHz}$ instrument in $\mathrm{CF}_{3} \mathrm{COOH}$, chemical shifts given on the $\delta$ scale from the signal of HMDS taken as 0 ) has two three-proton singlets at 3.58 and $3.55 \mathrm{ppm}$ (Ar$\mathrm{OCH}_{3}$ ); two one-proton doublets at 7.52 and $6.12 \mathrm{ppm}$ with $\mathrm{J}=9.8 \mathrm{~Hz}$ (protons at $\mathrm{C}_{4}$ and $\mathrm{C}_{3}$ ); and a singlet at $6.34 \mathrm{ppm}$ (proton at $\mathrm{C}_{8}$ ).

Acetic anhydride in pyridine formed acetylarscotin with $\mathrm{mp} 145-146^{\circ} \mathrm{C}$ [benzene-hexane $\left.(1: 1)\right], \mathrm{R}_{f}$ 0.5 [benzene-methanol $(9: 1)$ ]. The action of dimethyl sulfate on arscotin in absolute acetone with the addition of potassium carbonate gave a methyl ether with $\mathrm{mp} 100-101^{\circ} \mathrm{C}$ [benzene-herane $\left.(1: 1)\right], \mathrm{R}_{f} 0.77$ [benzene-methanol $(9: 1)$ ].

The NMR spectrum of acetylarscotin showed a new three-proton singlet at $2.22 \mathrm{ppm}$, and the other signals had shifted downfield. The three-proton singlets were shifted by 0.09 and $0.04 \mathrm{ppm}$, the signals of the protons at $\mathrm{C}_{3}$ and $\mathrm{C}_{4}$ by 0.15 and $0.17 \mathrm{ppm}$, and the one-proton singlet by $0.42 \mathrm{ppm}$. The latter circumstance shows the presence of a free proton adjacent to the $\mathrm{OH}$ group. The shift of the signals of the protons at $\mathrm{C}_{3}$ and $\mathrm{C}_{4}$ shows their para arrangement relative to the acetyl group, i.e., the $\mathrm{OH}$ is present at $\mathrm{C}_{7}$, position $\mathrm{C}_{8}$ is free, and the methoxy groups are the refore located at $\mathrm{C}_{5}$ and $\mathrm{C}_{6}$.

Because of the more acidic nature of this hydroxyl, in the UV spectrum with sodium acetate the re is a bathoch romic shift from $\lambda_{\max } 258$ to $287 \mathrm{~nm}$ and from $\lambda_{\max } 312$ to $331 \mathrm{~nm}(\log \varepsilon 3.63,3.76,3.95$, and 3.17, respectively).

On the basis of the results obtained, it is most probable that arscotin has the structure of 7-hydroxy5,6-dimethoxycoumarin.

\section{LITERATURE CITED}

1. M. I. Yusupov and G. P. Sidyakin, Khim. Prirodn. Soedin., 667 (1972).

Institute of the Chemistry of Plant Substances, Academy of Sciences of the Uzbek SSR. Translated from Khimiya Pri rodnykh Soedinenii, No. 3, p. 430, May-June, 1973. Original article submitted December 29, 1972 .

(c) 1975 Plenum Publishing Corponation, 227 West 17th Street, New York, N.Y. 10011. No part of this publication may be reproduced, stored in a retrieval system, or transmitted, in any form or by any means, electronic, mechanical, photocopying, microfilming, recording or otherwise, without written permission of the publisher. A copy of this article is available from the publisher for $\$ 15.00$. 